Terbit online pada laman web jurnal: http://jurnal.iaii.or.id

\begin{tabular}{c} 
JURNAI R RS'II \\
IAll $\begin{array}{l}\text { (Rekayasa Sistem dan Teknologi Informasi) } \\
\text { Vol. 5 No.4 (2021) } 639-646\end{array}$ \\
\hline
\end{tabular}

\title{
Pengenalan Logo Kendaraan Menggunakan Metode Local Binary Pattern dan Random Forest
}

\author{
Alda Putri Utami ${ }^{1}$, Febryanti Sthevanie ${ }^{2}$, Kurniawan Nur Ramadhani ${ }^{3}$ \\ 1,2,3Program Studi S1 Informatika, Fakultas Informatika, Universitas Telkom \\ ${ }^{1}$ aldddpt@student.telkomuniversity.ac.id, ${ }^{2}$ sthevanie@
}

\begin{abstract}
The vehicle logo is one of the features that can be used to identify a vehicle. Even so, a lot of Intelligent Transport System which are developed nowadays has yet to use a vehicle logo recognition system as one of its vehicle identification tools. Hence there are still cases of traffic crimes that haven't been able to be examined by the system, such as cases of counterfeiting vehicle license plates. Vehicle logo recognition itself could be done by using various feature extraction and classification methods. This research project uses the Local Binary Pattern feature extraction method which is often used for many kinds of image recognition systems. Then, the classification method used is Random Forest which is known to be effective and accurate for various classification problems. The data used for this study were as many as 2000 vehicle logo images consisting of 5 brand classes, namely Honda, Kia, Mazda, Mitsubishi, and Toyota. The results of the tests carried out obtained the best accuracy value of $88.89 \%$ for the front view logo image dataset, $77.03 \%$ for the side view logo image dataset, and $83 \%$ for the dataset with both types of images.
\end{abstract}

Keywords: recognition system, vehicle logo, local binary pattern, random forest

\begin{abstract}
Abstrak
Logo kendaraan merupakan salah satu ciri yang dapat digunakan untuk mengidentifikasi kendaraan. Meski begitu, banyak dari Sistem Transportasi Cerdas yang dikembangkan saat ini masih belum menggunakan sistem pengenalan logo kendaraan sebagai bagian dari alat identifikasi kendaraan. Karenanya masih ada kasus kejahatan lalu lintas yang luput dari pemeriksaan oleh sistem, seperti kasus pemalsuan pelat nomor kendaraan. Pengenalan logo kendaraan sendiri dapat dilakukan dengan menggunakan berbagai metode ekstraksi ciri dan klasifikasi. Penelitian ini menggunakan metode ekstraksi ciri Local Binary Pattern yang sudah sering digunakan untuk berbagai jenis sistem pengenalan citra. Kemudian, untuk metode klasifikasi yang digunakan adalah Random Forest yang dikenal efektif dan akurat untuk berbagai kasus klasifikasi. Data yang digunakan untuk penelitian ini adalah sebanyak 2000 citra logo kendaraan yang terdiri dari 5 kelas merek yaitu Honda, Kia, Mazda, Mitsubishi, dan Toyota. Hasil dari pengujian yang dilakukan memperoleh nilai akurasi terbaik sebesar $88,89 \%$ untuk dataset citra logo tampak depan, 77,03\% untuk dataset citra logo tampak samping, dan 83\% untuk dataset dengan kedua jenis citra.
\end{abstract}

Kata kunci: sistem pengenalan, logo kendaraan, local binary pattern, random forest

\section{Pendahuluan}

Teknologi Intelligent Transport System atau Sistem Transportasi Cerdas merupakan salah satu teknologi yang saat ini masih terus dikembangkan di Indonesia. Sebagai contoh, saat ini sudah ada sistem tilang elektronik yang digunakan di beberapa daerah di Indonesia. Pengembangan sistem ini dilakukan untuk mengatasi berbagai masalah di jalan raya seperti mendeteksi tindak kejahatan sehingga dapat meningkatkan keamanan lalu lintas di tengah mobilitas kendaraan yang padat.
Penggunaan Sistem Transportasi Cerdas biasanya hanya mengandalkan pelat nomor kendaraan sebagai alat identifikasi, seperti pada sistem tilang elektronik yang mendeteksi pelat nomor ganjil-genap. Oleh karena itu, masih ada beberapa kasus kejahatan lalu lintas yang tidak dapat dideteksi oleh sistem, contohnya adalah pada kasus pemalsuan pelat nomor. Pelat nomor yang digunakan bisa saja terdaftar, tetapi belum tentu sesuai dengan data sebenarnya sehingga masih diperlukan validasi. Hal ini dapat dilakukan dengan memeriksa kecocokan antara pelat nomor dengan tanda pengenal lain, seperti salah satunya adalah merek yang ada pada logo kendaraan. Berdasarkan hal tersebut, maka

Diterima Redaksi: 16-04-2021 | Selesai Revisi: 21-06-2021 | Diterbitkan Online: 20-08-2021 
diketahui bahwa pengembangan sistem pengenalan logo yang lebih baik dengan metode RF. Jika dilihat dari halkendaraan bisa menjadikan sistem yang sudah ada saat hal tersebut, terdapat kemungkinan bahwa penggunaan ini menjadi lebih baik lagi.

Selama beberapa tahun terakhir, sudah pernah dilakukan penelitian mengenai sistem pengenalan logo kendaraan metode ekstraksi ciri LBP dengan metode klasifikasi RF mampu mendapatkan hasil akurasi yang cukup baik pada sistem pengenalan logo kendaraan.

dengan menggunakan berbagai metode. Di tahun 2014, Dari hasil penelitian yang telah dilakukan, didapatkan terdapat penelitian yang membandingkan penggunaan bahwa metode LBP dan RF berhasil mendapatkan Image Matching dan Textural Features untuk akurasi sebesar 88,89\% untuk citra logo tampak depan, pengenalan 210 citra mendapatkan akurasi sebesar 77,03\% untuk citra logo tampak samping, dan $83 \%$ 96,2\% untuk Image Matching dan 90\% untuk Textural untuk kedua jenis citra. Dapat dilihat bahwa hasil Features [1]. Lalu Di tahun 2016, terdapat penelitian tersebut, terutama untuk kasus pengenalan logo untuk yang membandingkan penggunaan metode Speeded Up citra tampak samping, berhasil melampaui hasil pada Robust Features (SURF), Local Binary Pattern (LBP) penelitian sebelumnya [2].

dengan K-Nearest Neighbor (K-NN), Gray Level Co-

occurence Matrix (GLCM) dengan K-NN, serta 2. Metode Penelitian

kombinasi antara LBP dan GLCM dengan K-NN untuk dua kasus berbeda yang menghasilkan akurasi terbaik sebesar 99,5\% untuk kasus pertama dengan metode SURF dan akurasi sebesar $72 \%$ untuk kasus kedua dengan metode LBP dan K-NN [2].

Pada penelitian [2], kasus pertama menggunakan dataset desain citra logo kendaraan yang diambil dari situs web resmi merek kendaraan dan kasus kedua menggunakan dataset citra yang diambil menggunakan kamera digital. Meski begitu, pada kasus kedua citra yang digunakan terkesan tidak realistis dan kurang bervariasi karena diambil pada jarak dekat dan dengan pencahayaan yang memadai. Selain itu, akurasi yang dihasilkan dengan menggunakan metode LBP dan K-NN pada kasus kedua masih kurang baik. Jika dilihat dari penggunaan metodenya, penggunaan metode klasifikasi yang kurang tepat tampaknya merupakan penyebab dari rendahnya nilai akurasi pada penelitian tersebut. Karenanya, penggantian dengan metode klasifikasi lain memiliki kemungkinan untuk meningkatkan akurasi yang dihasilkan.

Oleh karena itu melanjutkan dari kasus untuk dataset kedua di penelitian sebelumnya [2], pada penelitian ini dibangun sistem pengenalan logo kendaraan menggunakan metode ekstraksi ciri LBP dan klasifikasi Random Forest (RF). Metode LBP sendiri sebelumnya telah umum digunakan untuk melakukan ekstraksi ciri pada citra, seperti pada sistem pengenalan wajah [3], iris mata [4], dan logo pada dokumen [5] serta mampu menghasilkan akurasi tinggi. Sementara itu, metode klasifikasi RF merupakan metode yang dikenal efektif sebagai alat prediksi serta akurat untuk klasifikasi dan regresi [6]. Penelitian [7] pada tahun 2017 menyatakan bahwa penggunaan metode RF menghasilkan akurasi yang lebih baik dibandingkan K-NN untuk klasifikasi multi kelas benih dan daun tanaman dengan metode ekstraksi ciri LBP. Kemudian pada tahun 2014, penelitian [8] juga telah membandingkan penggunaan metode klasifikasi RF dan Support Vector Machine (SVM) pada citra sayap lalat yang menggunakan metode LBP untuk ekstraksi ciri dan menunjukkan hasil akurasi

\subsection{Dataset}

Pada penelitian ini, data yang digunakan merupakan citra logo kendaraan dari 5 jenis merek kendaraan yang ada di Indonesia, yaitu Honda, Kia, Mazda, Mitsubishi, dan Toyota. Dataset diperoleh dari mengambil sebagian data yang ada pada The Vehicle Make and Model Recognition dataset (VMMRdb) di situs github.com yang dibahas pada jurnal [9]. Dataset yang digunakan terdiri dari 2000 citra logo kendaraan hasil cropping manual oleh penulis dengan masing-masing 400 citra untuk setiap merek. Dari citra tersebut, pada percobaan untuk seluruh dataset menggunakan 1800 citra untuk pelatihan dan validasi dengan Stratified K-Fold Cross Validation, sementara 200 citra digunakan untuk melakukan pengujian.

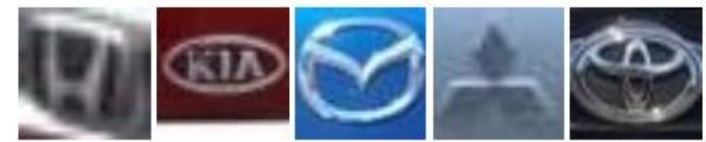

Gambar 1. Sampel Dataset

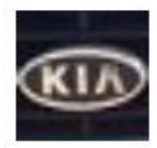

Gambar 2. Sampel Jenis Citra Tampak Depan

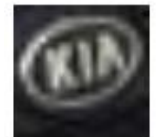

Gambar 3. Sampel Jenis Citra Tampak Samping

Dari 2000 citra pada dataset, di antaranya terdapat dua jenis citra logo kendaraan berdasarkan sisi pengambilan gambarnya yaitu 1255 citra logo kendaraan yang diambil dari sisi depan dan 745 citra logo kendaraan yang diambil dari sisi samping. Percobaan untuk dataset citra yang diambil dari sisi depan menggunakan 1129 citra untuk pelatihan dan validasi serta 126 citra untuk pengujian, sementara percobaan untuk dataset citra yang 
diambil dari sisi samping menggunakan 671 citra untuk Proses pelatihan dan pengujian dilakukan dengan tiga pelatihan dan validasi serta 74 citra untuk pengujian.

jenis citra masukan, yaitu dataset citra logo kendaraan yang diambil dari sisi depan, dataset citra logo kendaraan yang diambil dari sisi samping, dan seluruh

\subsection{Alur Penelitian}

dataset citra logo kendaraan dengan kedua jenis sisi

Penelitian dilakukan dengan melalui dua proses yaitu dataset citra logo ke
pelatihan dan pengujian. Gambar 4 menjelaskan alur pengambilan gambar.

proses pelatihan yang dimulai oleh tahap masuknya citra

data latih dan kemudian dilakukannya praproses citra,

\subsection{Praproses Citra}

ekstraksi ciri, dan pelatihan sehingga menghasilkan Dua tahap praproses dilakukan pada citra sehingga citra model yang selanjutnya digunakan pada proses yang digunakan sesuai dengan kebutuhan pengolahan. pengujian seperti pada Gambar 5.

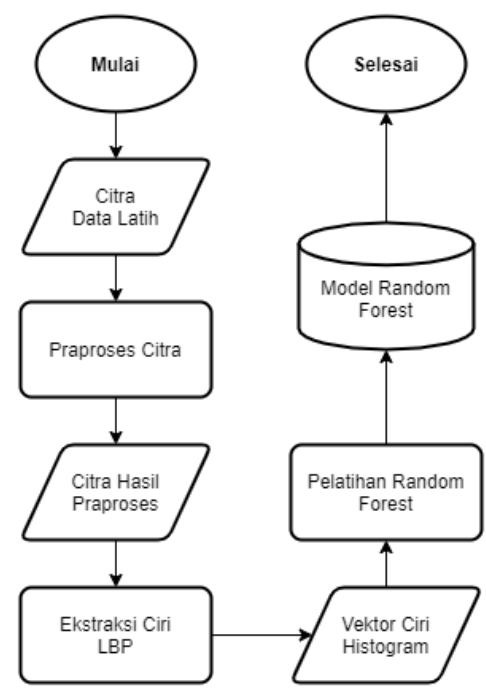

Gambar 4. Alur Proses Pelatihan Pertama-tama, dilakukan resize pada citra agar ukurannya menjadi seragam yaitu 30 x 30 piksel. Kemudian, citra yang awalnya berwarna RGB diubah menjadi grayscale.

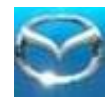

Gambar 6. Citra Asli

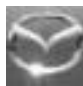

Gambar 7. Citra Hasil Praproses

Pada Gambar 6 dan Gambar 7 dapat dilihat contoh perbedaan citra sebelum dilakukannya praproses di Gambar 6 dan setelah praproses di Gambar 7.

\subsection{Local Binary Pattern}

Local Binary Pattern (LBP) adalah sebuah operator untuk deskripsi tekstur berdasarkan perbedaan antara nilai piksel pada citra dengan piksel-piksel tetangganya Pada Gambar 5 dapat dilihat bahwa citra data uji melalui dengan cara menghitung selisih nilai keabuan yang tahapan yang hampir sama dengan citra data latih pada menghasilkan sebuah kode biner untuk setiap piksel proses pelatihan, yaitu tahap praproses citra dan tersebut [10], [11].

ekstraksi ciri. Perbedaannya adalah pada klasifikasi data uji yang dilakukan menggunakan model yang telah diperoleh sebelumnya dari proses pelatihan sehingga menghasilkan hasil klasifikasi berupa kelas prediksi.

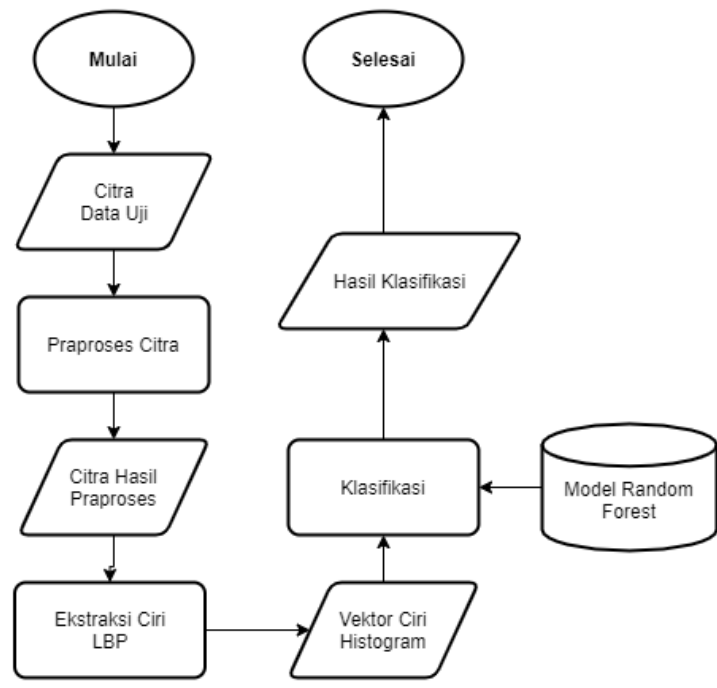

Gambar 5. Alur Proses Pengujian

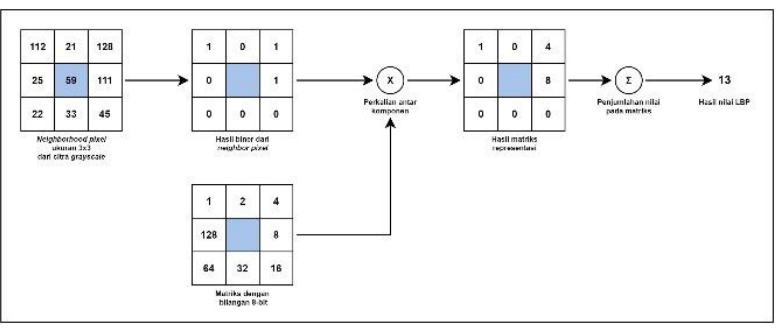

Gambar 8. Contoh Cara Kerja LBP [10]

Operator LBP bersifat invariant terhadap skala keabuan pada citra. Operator LBP ini menggunakan nilai titiktitik sampel sebanyak $\mathrm{P}(\mathrm{P}>1)$ di sekeliling piksel yang sedang diproses dengan jarak sejauh radius $R(R>0)$ [11] dan memiliki persamaan sebagai berikut:

$$
L B P_{P, R}=\sum_{p=0}^{P-1} s\left(g_{p}-g_{c}\right) 2^{p}
$$

dengan $\operatorname{LBP}_{\mathrm{P}, \mathrm{R}}$ adalah nilai LBP dari piksel yang diproses pada citra $g_{p}$ nilai keabuan dari titik-titik sampel yang digunakan, dan $\mathrm{g}_{\mathrm{c}}$ merupakan nilai keabuan piksel yang diproses pada citra. Sementara, fungsi $\mathrm{s}(\mathrm{x})$ didefinisikan sebagai:

DOI: https://doi.org/10.29207/resti.v5i4.3085

Lisensi: Creative Commons Attribution 4.0 International (CC BY 4.0) 


$$
s(x)=\left\{\begin{array}{l}
1, \text { jika } x \geq 0 \\
0, \text { jika } x<0
\end{array}\right.
$$

pada citra kemudian menghasilkan vektor ciri yang direpresentasikan oleh histogram berukuran 256 bins.

(2)

2.5. Random Forest

Tahapan yang dilakukan pada proses LBP dimulai dari Random Forest (RF) adalah metode klasifikasi ensemble melakukan penghitungan selisih nilai keabuan antara learning yang terdiri dari kumpulan pohon keputusan setiap piksel pada citra dengan titik-titik sampel yang yang setiap hasil pohonnya bernilai satu unit suara untuk diambil dari piksel-piksel tetangganya. Hasil dari memilih kelas yang paling sesuai untuk suatu data penghitungan tersebut adalah suatu kode biner masukan X dengan sistem pengambilan suara terbanyak sepanjang jumlah titik sampel yang telah ditentukan. atau voting. Setiap pohon keputusan dalam RF ini Berikutnya, kode ini digunakan untuk menghitung nilai dibangun dengan mengambil sampel data secara acak LBP dari piksel tersebut. Nilai-nilai LBP dari piksel dari data masukan [6], [12].

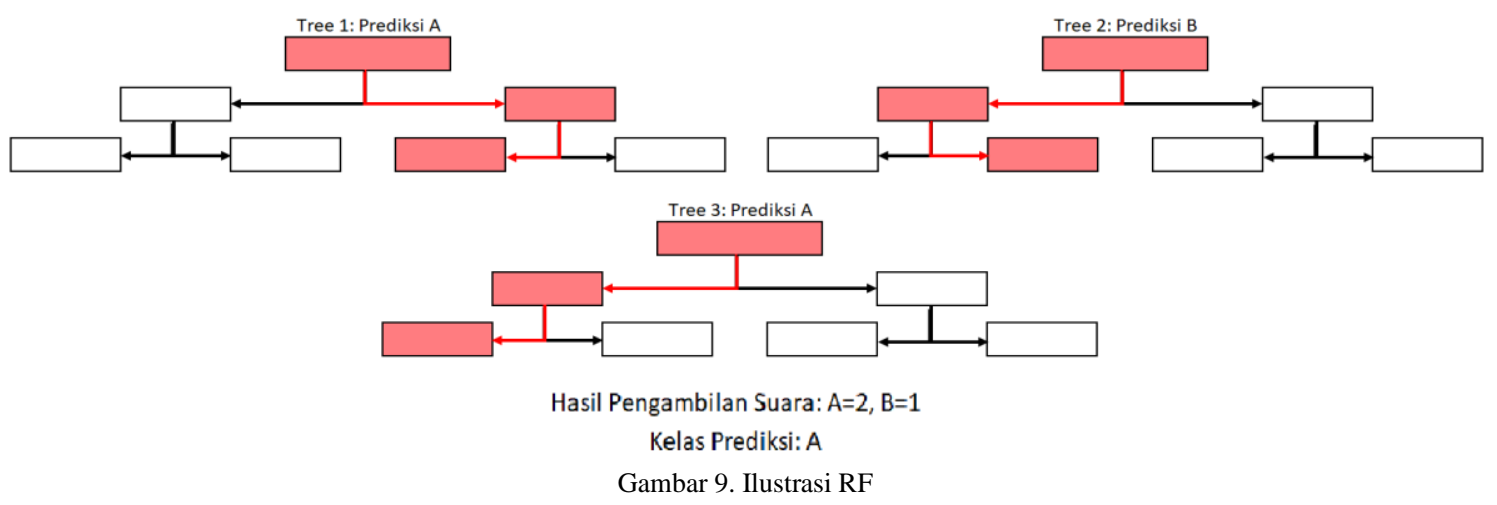

Model klasifikasi RF dibentuk dengan menggunakan jenis citra, yaitu 1129 citra untuk yang diambil dari sisi vektor ciri hasil ekstraksi dengan LBP terhadap data depan, 671 citra untuk yang diambil dari sisi samping, latih. Model ini yang kemudian digunakan untuk dan 1800 citra untuk kedua jenis citra yang ada pada melakukan prediksi pada data uji.

Tahapan yang dilakukan untuk mendapatkan hasil prediksi data uji dengan metode RF, pertama adalah dibuatnya pohon keputusan sesuai jumlah yang telah ditentukan. Setiap pohon akan mengklasifikasikan data berdasarkan ketentuannya masing-masing yang didapatkan dari proses pelatihan. Hasil dari setiap pohon Tahap yang pertama dilakukan untuk mengetahui

ini kemudian digunakan sebagai satu unit suara untuk pengaruh dari radius $\mathrm{R}$ dan jumlah titik-titik sampel $\mathrm{P}$ penentuan kelas dari suatu data uji.

\subsection{Evaluasi}

dataset. Tahap ini dilakukan untuk mengetahui pengaruh dari berbagai nilai parameter yang digunakan pada proses ekstraksi ciri dan klasifikasi. Pelatihan dilakukan dengan membagi citra sebagai data uji dan data validasi menggunakan metode Stratified K-Fold Cross Validation dengan nilai $\mathrm{k}=10$. pada metode LBP. Kemudian, tahap yang kedua dilakukan untuk mengetahui pengaruh jumlah pohon $\mathrm{n}_{\text {tree }}$ yang digunakan pada metode RF. Pada kedua Evaluasi dilakukan terhadap hasil pengujian dengan tahapan akan dievaluasi nilai akurasi terendah, akurasi menggunakan confusion matrix dan nilai akurasi. Pada tertinggi, dan rata-rata akurasi yang diperoleh dari 10 confusion matrix, didapatkan empat buah hasil, yaitu percobaan yang dilakukan. true positives, false positives, false negatives, dan true negatives. Keempat hasil tersebut kemudian digunakan untuk menghitung akurasi dengan menggunakan persamaan:

Akurasi $=\frac{T P+T N}{T P+F P+F N+T N}$

Untuk tahap yang pertama, dilakukan percobaan menggunakan ukuran radius $\mathrm{R} 1$ sampai 6 dan jumlah titik-titik sampel $\mathrm{P}$ sebanyak 8, 16, 24, 32, 40, dan 48 sehingga diketahui kombinasi $\mathrm{R}$ dan $\mathrm{P}$ yang terbaik.

(3) Untuk setiap kali percobaan, dilakukan dengan $n_{\text {tree }}=64$.

Berdasarkan Tabel 1 nilai rata-rata akurasi terbaik dengan TP adalah jumlah data true positives, TN adalah diperoleh dengan kombinasi nilai $\mathrm{R}=5$ dan $\mathrm{P}=8$ untuk jumlah data true negatives, FP adalah jumlah data false pelatihan dengan citra tampak depan, citra tampak positives, dan FN adalah jumlah data false negatives.

\section{Hasil dan Pembahasan}

\subsection{Hasil Pelatihan}

samping, maupun keduanya. Pelatihan dengan citra tampak depan memperoleh rata-rata akurasi terbaik yang paling tinggi di antara ketiga jenis citra yang digunakan yaitu $85,66 \%$, sementara untuk pelatihan Sebelum dilakukannya pengujian, pelatihan dilakukan dengan citra tampak samping memperoleh rata-rata menggunakan masing-masing data latih untuk setiap akurasi terbaik 67,81\%, dan untuk pelatihan dengan 
kedua jenis citra memperoleh rata-rata akurasi terbaik jumlah $\mathrm{n}_{\text {tree }}$ yang digunakan untuk pengujian adalah 64 , $78,22 \%$. Dapat dilihat bahwa nilai rata-rata akurasi 72, 80, 88, 96, 104, 112, 120, 128, 256, dan $512 \mathrm{n}_{\text {tree }}$. terbaik diperoleh dengan nilai $\mathrm{P}=8$ di semua nilai $\mathrm{R}$. Sementara, nilai $\mathrm{R}$ yang semakin besar berpengaruh dalam meningkatkan akurasi yang dihasilkan sampai dengan $\mathrm{R}=5$, kemudian akurasinya menurun pada $\mathrm{R}=$ 6.

Tabel 1. Hasil Pelatihan Pengaruh R dan $\mathrm{P}$

\begin{tabular}{|c|c|c|c|c|c|}
\hline Jenis Citra & $\mathrm{R}$ & $\mathrm{P}$ & $\begin{array}{c}\text { Akurasi } \\
\text { Terendah } \\
(\%)\end{array}$ & $\begin{array}{c}\text { Akurasi } \\
\text { Tertinggi } \\
(\%)\end{array}$ & $\begin{array}{c}\text { Rata-rata } \\
\text { Akurasi } \\
(\%)\end{array}$ \\
\hline \multirow{17}{*}{$\begin{array}{c}\text { Citra } \\
\text { Tampak } \\
\text { Depan }\end{array}$} & 1 & 8 & 67,26 & 78,76 & 73,43 \\
\hline & 2 & 8 & 75,22 & 84,96 & 79,99 \\
\hline & 2 & 16 & 69,91 & 84,82 & 77,78 \\
\hline & 3 & 8 & 80,53 & 89,38 & 85,12 \\
\hline & 3 & 16 & 72,57 & 84,82 & 78,66 \\
\hline & 3 & 24 & 73,45 & 82,14 & 76,71 \\
\hline & 4 & 8 & 83,19 & 86,73 & 85,53 \\
\hline & 4 & 16 & 72,57 & 84,96 & 79,81 \\
\hline & 4 & 32 & 63,72 & 78,76 & 68,47 \\
\hline & 5 & 8 & 78,76 & 90,27 & 85,66 \\
\hline & 5 & 16 & 72,57 & 86,73 & 80,7 \\
\hline & 5 & 24 & 73,45 & 86,73 & 80,96 \\
\hline & 5 & 40 & 65,49 & 75,22 & 70,06 \\
\hline & 6 & 8 & 79,65 & 87,5 & 82,73 \\
\hline & 6 & 16 & 74,34 & 88,39 & 82,12 \\
\hline & 6 & 24 & 74,34 & 86,61 & 79,61 \\
\hline & 6 & 48 & 53,1 & 65,18 & 58,38 \\
\hline \multirow{17}{*}{$\begin{array}{c}\text { Citra } \\
\text { Tampak } \\
\text { Samping }\end{array}$} & 1 & 8 & 50 & 64,18 & 56,19 \\
\hline & 2 & 8 & 58,82 & 68,66 & 64,54 \\
\hline & 2 & 16 & 46,27 & 61,19 & 55,44 \\
\hline & 3 & 8 & 57,35 & 74,63 & 66,63 \\
\hline & 3 & 16 & 47,76 & 65,67 & 57,52 \\
\hline & 3 & 24 & 47,76 & 62,69 & 53,8 \\
\hline & 4 & 8 & 61,19 & 73,53 & 66,61 \\
\hline & 4 & 16 & 46,27 & 65,67 & 54,99 \\
\hline & 4 & 32 & 35,82 & 57,35 & 46,18 \\
\hline & 5 & 8 & $\mathbf{5 9 , 7}$ & 76,12 & 67,81 \\
\hline & 5 & 16 & 50,72 & 61,19 & 56,48 \\
\hline & 5 & 24 & 42,65 & 55,22 & 51,13 \\
\hline & 5 & 40 & 37,31 & 56,72 & 47,7 \\
\hline & 6 & 8 & 61,19 & 73,13 & 67,06 \\
\hline & 6 & 16 & 49,25 & 70,15 & 60,5 \\
\hline & 6 & 24 & 41,79 & 68,66 & 55,14 \\
\hline & 6 & 48 & 29,85 & 49,25 & 37,11 \\
\hline \multirow{17}{*}{$\begin{array}{c}\text { Kedua } \\
\text { Jenis Citra }\end{array}$} & 1 & 8 & 61,67 & 71,67 & 66,39 \\
\hline & 2 & 8 & 68,89 & 73,89 & 71,5 \\
\hline & 2 & 16 & 62,78 & 73,33 & 67,22 \\
\hline & 3 & 8 & 68,89 & 80 & 75,16 \\
\hline & 3 & 16 & 62,22 & 70 & 67,05 \\
\hline & 3 & 24 & 61,67 & 69,44 & 65,67 \\
\hline & 4 & 8 & 71,67 & 81,11 & 76,72 \\
\hline & 4 & 16 & 63,33 & 70,56 & 67,94 \\
\hline & 4 & 32 & 53,33 & 62,78 & 59,67 \\
\hline & 5 & 8 & 70,56 & 82,22 & 78,22 \\
\hline & 5 & 16 & 65,56 & 73,89 & 70,27 \\
\hline & 5 & 24 & 64,44 & 74,44 & 68,94 \\
\hline & 5 & 40 & 53,89 & 63,89 & 60,67 \\
\hline & 6 & 8 & 70 & 77,78 & 74,56 \\
\hline & 6 & 16 & 66,67 & 78,89 & 72,28 \\
\hline & 6 & 24 & 65 & 76,11 & 69,61 \\
\hline & 6 & 48 & 39,44 & 55 & 49,11 \\
\hline
\end{tabular}

\begin{tabular}{|c|c|c|c|c|}
\hline Jenis Citra & $\mathrm{n}_{\text {tree }}$ & $\begin{array}{c}\text { Akurasi } \\
\text { Terendah } \\
(\%)\end{array}$ & $\begin{array}{c}\text { Akurasi } \\
\text { Tertinggi } \\
(\%)\end{array}$ & $\begin{array}{c}\text { Rata-rata } \\
\text { Akurasi } \\
(\%)\end{array}$ \\
\hline \multirow{11}{*}{$\begin{array}{c}\text { Citra } \\
\text { Tampak } \\
\text { Depan }\end{array}$} & 64 & 78,76 & 90,27 & 85,66 \\
\hline & 72 & 80,53 & 90,27 & 84,94 \\
\hline & 80 & 84,82 & 88,5 & 86,01 \\
\hline & 88 & 83,93 & 90,27 & 86,36 \\
\hline & 96 & 80,53 & 90,27 & 85,83 \\
\hline & 104 & 83,04 & 92,04 & 86,98 \\
\hline & 112 & 84,96 & 91,15 & 87,25 \\
\hline & 120 & 85,71 & 89,38 & 87,24 \\
\hline & 128 & 84,96 & 92,92 & 88,13 \\
\hline & 256 & 83,19 & 92,92 & 88,04 \\
\hline & 512 & 84,96 & 93,18 & 88,4 \\
\hline \multirow{11}{*}{$\begin{array}{c}\text { Citra } \\
\text { Tampak } \\
\text { Samping }\end{array}$} & 64 & 59,7 & 76,12 & 67,81 \\
\hline & 72 & 61,19 & 77,61 & 67,66 \\
\hline & 80 & 61,19 & 79,1 & 67,8 \\
\hline & 88 & 56,72 & 79,1 & 66,17 \\
\hline & 96 & 58,21 & 74,63 & 67,51 \\
\hline & 104 & 58,21 & 85,07 & 68,85 \\
\hline & 112 & 64,18 & 73,13 & 68,1 \\
\hline & 120 & 59,7 & 77,61 & 69,56 \\
\hline & 128 & 65,67 & 79,1 & 71,24 \\
\hline & 256 & 64,18 & 80,6 & 71,68 \\
\hline & 512 & 65,67 & 82,09 & 71,98 \\
\hline \multirow{11}{*}{$\begin{array}{l}\text { Kedua Jenis } \\
\text { Citra }\end{array}$} & 64 & 70,56 & 82,22 & 78,22 \\
\hline & 72 & 70 & 80,56 & 76,39 \\
\hline & 80 & 71,11 & 82,78 & 78,05 \\
\hline & 88 & 72,78 & 82,22 & 77,89 \\
\hline & 96 & 73,89 & 82,22 & 78,05 \\
\hline & 104 & 72,22 & 82,22 & 77,22 \\
\hline & 112 & 71,67 & 84,44 & 78,67 \\
\hline & 120 & 72,22 & 82,78 & 78,39 \\
\hline & 128 & 75,56 & 82,78 & 79,22 \\
\hline & 256 & 71,11 & 82,78 & 79,17 \\
\hline & 512 & 74,44 & 82,22 & 79,56 \\
\hline
\end{tabular}

Berdasarkan hasil dari Tabel 2 pada penggunaan jenis citra tampak depan, citra tampak samping, maupun keduanya dapat dilihat bahwa jumlah 128, 256, dan 512 $\mathrm{n}_{\text {tree }}$ memberikan nilai rata-rata akurasi terbaik dibandingkan dengan jumlah lainnya. Meski begitu, perbedaannya tidak signifikan, sementara beban komputasinya lebih berat pada $\mathrm{n}_{\text {tree }}=256$ dan $\mathrm{n}_{\text {tree }}=512$ jika dibandingkan dengan $n_{\text {tree }}=128$. Oleh karena itu, jumlah $\mathrm{n}_{\text {tree }}=128$ dianggap dapat memberikan nilai ratarata akurasi terbaik, yaitu sebesar $88,13 \%$ untuk citra tampak depan, 71,24\% untuk citra tampak samping, dan $79,22 \%$ untuk kedua jenis citra.

\subsection{Hasil Pengujian}

Pengujian dilakukan menggunakan masing-masing data latih untuk setiap jenis citra, yaitu 126 citra untuk yang diambil dari sisi depan, 74 citra untuk yang diambil dari sisi samping, dan 200 citra untuk kedua jenis citra yang ada pada dataset. Pada pengujian, digunakan pengaturan terbaik yang telah didapatkan dari proses pelatihan.

Tahapan berikutnya dilakukan dengan nilai $\mathrm{R}$ dan $\mathrm{P}$ Parameter $\mathrm{LBP}$ yang digunakan adalah $\mathrm{R}=5$ dan $\mathrm{P}=8$, terbaik yang sudah diperoleh sebelumnya. Sementara, serta parameter untuk RF adalah $\mathrm{n}_{\text {tree }}=128$. 
Berdasarkan pengujian yang dilakukan terhadap citra Berikutnya, dari confusion matrix untuk pengujian tampak depan maka dihasilkan confusion matrix yang terhadap citra tampak samping di Gambar 11, dapat dilihat pada Gambar 10.

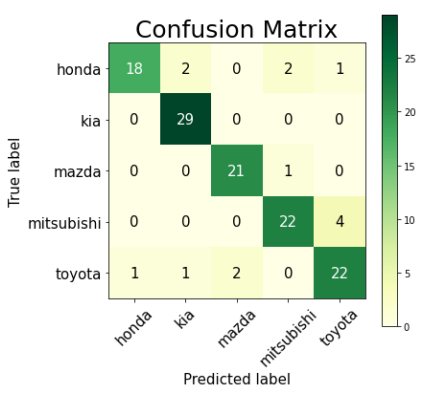

Gambar 10. Confusion Matrix Hasil Pengujian Terhadap Citra Tampak Depan

Berikutnya, dari confusion matrix untuk pengujian terhadap citra tampak depan di Gambar 10, didapatkan penilaian kinerja klasifikasi yang memuat nilai precision, recall, dan $f 1$-score untuk setiap kelas merek, serta rata-ratanya secara keseluruhan dan akurasinya pada Tabel 3.

Tabel 3. Penilaian Kinerja Hasil Pengujian Terhadap Citra Tampak

\begin{tabular}{ccccc}
\multicolumn{5}{c}{ Depan } \\
\hline & $\begin{array}{c}\text { Precision } \\
(\%)\end{array}$ & $\begin{array}{c}\text { Recall } \\
(\%)\end{array}$ & $\begin{array}{c}\text { F1-Score } \\
(\%)\end{array}$ & $\begin{array}{c}\text { Jumlah } \\
\text { Data }\end{array}$ \\
\hline Honda & 95 & 78 & 86 & 23 \\
Kia & 91 & 100 & 95 & 29 \\
Mazda & 91 & 95 & 93 & 22 \\
Mitsubishi & 88 & 85 & 86 & 26 \\
Toyota & 81 & 85 & 83 & 26 \\
\hline Akurasi & & & 88,89 & 126 \\
Weighted & \multirow{2}{*}{89} & 89 & 89 & 126 \\
Average & & \multirow{2}{*}{8} &
\end{tabular}

Berdasarkan penilaian pada Tabel 3, dapat dilihat untuk hasil pengujian dengan menggunakan pengaturan terbaik untuk citra tampak depan memperoleh rata-rata precision, recall, dan $f 1$-score yang diperoleh adalah sama yaitu $89 \%$. Kemudian, untuk hasil akurasinya adalah $88,89 \%$ dengan rincian data yang tepat diprediksi yaitu 18 dari 23 data uji untuk merek honda, 29 dari 29 data uji untuk merek kia, 21 dari 22 data uji untuk merek mazda, 22 dari 26 data uji untuk merek mitsubishi, dan 22 dari 26 data uji untuk merek toyota.

Selanjutnya, untuk pengujian yang dilakukan terhadap citra tampak samping dihasilkan confusion matrix yang dapat dilihat pada Gambar 11.

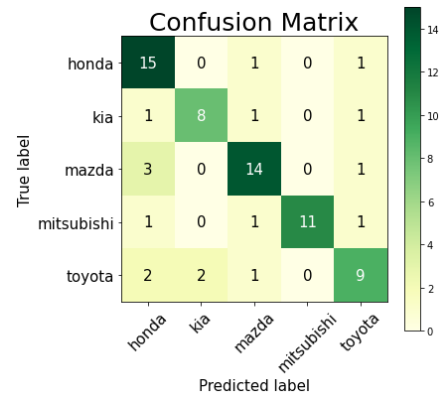

Gambar 11. Confusion Matrix Hasil Pengujian Terhadap Citra Tampak Samping didapatkan penilaian kinerja klasifikasi pada tabel Tabel 4.

\begin{tabular}{ccccc}
\multicolumn{5}{c}{ Tabel 4. Penilaian Kinerja Hasil Pengujian Terhadap Citra Tampak } \\
Samping
\end{tabular}

Berdasarkan penilaian pada Tabel 4, dapat dilihat untuk hasil pengujian dengan menggunakan pengaturan terbaik untuk citra tampak samping memperoleh ratarata precision sebesar $78 \%$, recall sebesar $77 \%$, dan $f 1$ score sebesar $77 \%$. Sementara, untuk hasil akurasinya adalah $77,03 \%$ dengan rincian data yang tepat diprediksi yaitu 15 dari 17 data uji untuk merek honda, 8 dari 11 data uji untuk merek kia, 14 dari 18 data uji untuk merek mazda, 11 dari 14 data uji untuk merek mitsubishi, dan 9 dari 14 data uji untuk merek toyota.

Terakhir, untuk pengujian yang dilakukan terhadap kedua jenis citra dihasilkan confusion matrix yang dapat dilihat pada Gambar 12

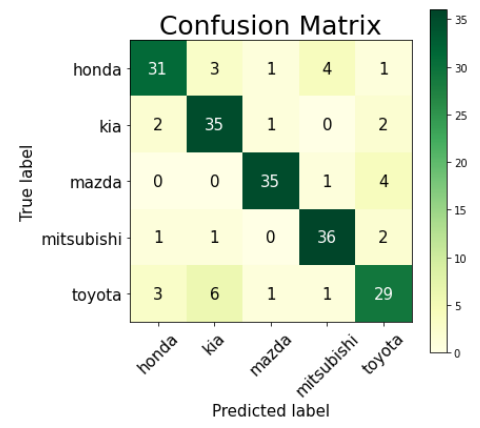

Gambar 12. Confusion Matrix Hasil Pengujian Terhadap Kedua Jenis Citra

Lalu berdasarkan confusion matrix untuk pengujian terhadap kedua jenis citra di Gambar 12, didapatkan penilaian kinerja klasifikasi pada Tabel 5.

\begin{tabular}{|c|c|c|c|c|}
\hline & $\begin{array}{c}\text { Precision } \\
(\%)\end{array}$ & $\begin{array}{c}\text { Recall } \\
(\%)\end{array}$ & $\begin{array}{c}\text { F1-Score } \\
(\%)\end{array}$ & $\begin{array}{c}\text { Jumlah } \\
\text { Data } \\
\end{array}$ \\
\hline Honda & 84 & 78 & 81 & 40 \\
\hline Kia & 78 & 88 & 82 & 40 \\
\hline Mazda & 92 & 88 & 90 & 40 \\
\hline Mitsubishi & 86 & 90 & 88 & 40 \\
\hline Toyota & 76 & 72 & 74 & 40 \\
\hline Akurasi & & & 83 & 200 \\
\hline $\begin{array}{l}\text { Weighted } \\
\text { Average }\end{array}$ & 83 & 83 & 83 & 200 \\
\hline
\end{tabular}

DOI: https://doi.org/10.29207/resti.v5i4.3085

Lisensi: Creative Commons Attribution 4.0 International (CC BY 4.0) 
Selain itu, kesalahan prediksi juga dapat disebabkan oleh Penilaian pada tabel di atas menunjukkan bahwa hasil tampilan logo yang ada pada citra. Pada pengujian yang pengujian dengan menggunakan pengaturan terbaik dilakukan terhadap citra tampak samping dan kedua untuk kedua jenis citra memperoleh nilai rata-rata jenis citra, terdapat citra dengan tampilan logo yang precision, recall, dan $f 1$-score yang sama yaitu $83 \%$. beragam karena diambil dari berbagai sisi. Berbeda Hasil akurasinya pun sebesar $83 \%$ dengan rincian data dengan pada pengujian yang dilakukan terhadap citra yang tepat diprediksi yaitu 31 dari 40 data uji untuk tampak depan yang datanya lebih seragam dengan merek honda, 35 dari 40 data uji untuk merek kia, 35 dari pengambilan gambar yang dilakukan dari satu sisi saja, 40 data uji untuk merek mazda, 36 dari 40 data uji untuk citra logo yang diambil dari berbagai sisi menyebabkan merek mitsubishi, dan 29 dari 40 data uji untuk merek tampilan logo seperti terdistorsi sehingga menyebabkan toyota.

\subsection{Analisis Hasil Pengujian}

Penilaian kinerja dari hasil pengujian terhadap citra dari berbagai sisi. tampak depan, citra tampak samping, dan kedua jenis citra pada Tabel 3, Tabel 4, dan Tabel 5 menunjukkan bahwa hasil akurasi terbaik diperoleh pada pengujian dengan citra tampak depan sebesar $88,89 \%$. Sementara pada pengujian dengan citra tampak samping diperoleh akurasi sebesar $77,03 \%$ dan pada pengujian dengan kedua jenis citra diperoleh akurasi sebesar $83 \%$. Hal ini menunjukkan bahwa sistem mampu memberikan hasil yang lebih baik dengan tampilan logo pada citra yang lebih seragam dibandingkan dengan yang memiliki berbagai variasi yang dalam kasus ini adalah pengambilan gambar dari berbagai sisi.

Kemudian jika dilihat hasil berdasarkan confusion matrix yang ada pada Gambar 10, Gambar 11, dan Gambar 12, masih terdapat beberapa data yang salah diprediksi. Hal ini bisa terjadi dikarenakan beberapa hal, yang pertama dapat dilihat dengan membandingkan jarak Euclidean vektor ciri histogram citra yang salah diprediksi dengan histogram data uji pada kelas sebenarnya dan kelas prediksi.

Tabel 6. Perbandingan Jarak Euclidean Pada Sampel Data Salah Prediksi

\begin{tabular}{|c|c|c|c|c|c|}
\hline \multirow[b]{3}{*}{ No. } & \multirow[b]{3}{*}{ Citra } & \multicolumn{2}{|c|}{ Prediksi } & \multirow{2}{*}{\multicolumn{2}{|c|}{ Kelas Prediksi }} \\
\hline & & Kelas & ebenarnya & & \\
\hline & & Kelas & $\begin{array}{c}\text { Jarak } \\
\text { Euclidean }\end{array}$ & Kelas & $\begin{array}{c}\text { Jarak } \\
\text { Euclidean }\end{array}$ \\
\hline 1 & & Honda & 133,62 & $\begin{array}{l}\text { Mitsu- } \\
\text { bishi }\end{array}$ & 126,29 \\
\hline 2 & & $\begin{array}{c}\text { Mitsu- } \\
\text { bishi }\end{array}$ & 93,85 & Kia & 88,99 \\
\hline 3 & & Mazda & 98,34 & Toyota & 96,55 \\
\hline
\end{tabular}

Bisa dilihat pada Tabel 6, beberapa contoh data yang salah prediksi pada pengujian dengan kedua jenis citra menunjukkan bahwa vektor cirinya memiliki jarak Euclidean yang lebih dekat dengan kelas prediksi dibandingkan kelas sebenarnya. Hal ini menunjukkan kalau dalam beberapa kasus, sistem tidak berhasil mengekstraksi ciri dengan baik sehingga vektor ciri yang diperoleh dari citra tidak dapat mewakili kelas sebenarnya dari citra tersebut.

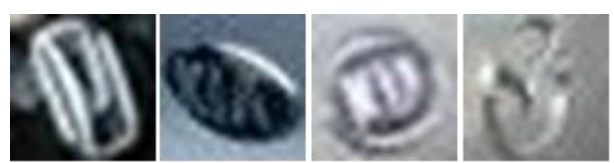

Gambar 13. Sampel Data Salah Prediksi

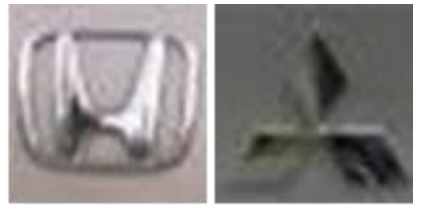

Gambar 14. Sampel Data Salah Prediksi

Alasan lain terjadinya kesalahan prediksi yaitu bisa dikarenakan adanya cahaya yang memantul pada logo sehingga sistem mengenali logo sebagai kelas yang berbeda dari kelas sebenarnya. Sorot cahaya yang memantul pada logo kendaraan dapat membuat bentuk logo tampak terputus di beberapa bagian atau menghilangkan beberapa detail seperti garis tepi yang membedakan antara logo dengan background pada citra. Gambar 14 menunjukkan contoh beberapa citra dengan sorot cahaya yang memantul pada logonya.

\section{Kesimpulan}

Pada penelitian ini telah berhasil dibangun sistem pengenalan logo kendaraan menggunakan metode Local Binary Pattern (LBP) dan Random Forest (RF). Penelitian ini melakukan pengenalan logo kendaraan pada citra logo kendaraan untuk dua kasus, yaitu citra logo kendaraan tampak depan dan citra logo kendaraan tampak samping dengan total citra sebanyak 200. Pemilihan nilai parameter radius $\mathrm{R}$ dan titik sampel $\mathrm{P}$ pada metode LBP serta parameter jumlah pohon $n_{\text {tree }}$ pada metode RF memengaruhi hasil kinerja akurasi yang diperoleh. Pada penelitian ini, hasil pengujian terbaik yaitu nilai akurasi $88,89 \%$ untuk citra logo tampak depan, 77,03\% untuk citra logo tampak samping, dan $83 \%$ untuk kedua jenis citra diperoleh dengan nilai parameter $\mathrm{R}=5$ dan $\mathrm{P}=8$, serta jumlah $\mathrm{n}_{\text {tree }}=128$.

Kontribusi dari penelitian ini adalah membuka peluang penelitian untuk membangun sistem pengenalan logo kendaraan yang memiliki tingkat akurasi yang tinggi.

DOI: https://doi.org/10.29207/resti.v5i4.3085

Lisensi: Creative Commons Attribution 4.0 International (CC BY 4.0) 
Penelitian ini menggunakan metode klasifikasi RF yang Daftar Rujukan

merupakan metode klasifikasi yang merupakan metode klasifikasi gabungan dan bekerja lebih baik dibandingkan metode klasifikasi tunggal seperti K-NN yang digunakan pada penelitian sebelumnya[2]. Penelitian selanjutnya diharapkan bisa mengeksplorasi metode klasifikasi yang lebih baik daripada metode bekerja dengan data realtime yang akan sangat bermanfaat untuk membantu proses pengenalan kendaraan pada video lalu lintas.

Berdasarkan hasil pengujian yang telah dilakukan, diketahui masih ada beberapa kelemahan dari sistem yang dibangun di antaranya belum mampu mengklasifikasikan citra dengan tampilan logo yang bervariasi atau dalam kasus ini diambil dari berbagai sisi, lalu sistem juga masih menggunakan citra logo secara utuh sehingga background pada citra masih dihitung ke dalam vektor ciri yang digunakan untuk klasifikasi.

Dari hasil pengujian yang telah dilakukan serta kelemahan yang ditemukan dari sistem, maka saran untuk penelitian kedepannya adalah untuk melakukan praproses perbaikan arah pengambilan gambar atau proyeksi sehingga tampilan logo yang digunakan lebih seragam. Selain itu, bisa juga dicoba dilakukan praproses untuk menghilangkan background pada citra sehingga citra yang diolah hanya terdiri dari logo kendaraannya saja. Pada penelitian ini juga baru berfokus pada klasifikasi dan belum berfokus pada deteksi sehingga untuk pengembangan penelitian berikutnya bisa ditambahkan metode untuk deteksi logo kendaraan.
[1] N. Farajzadeh and N. S. Rezaei, 2014. Vehicle Logo Recognition using Image Matching and Textural Features, in: Scientific Cooperations International Workshops on Electrical and Computer Engineering Subfields.

[2] S. Albera, 2016. Vehicle Logo Recognition Using Image Processing Methods, Atilim University.

[3] W. H. Lin, P. Wang, and C. F. Tsai, 2016. Face recognition using support vector model classifier for user authentication, Electronic Commerce Research and Applications, 18, pp. 7182.

[4] N. S. Sarode, A. M. Patil, and N. S. S. D. A. M. Patil, 2015. Iris Recognition using LBP with Classifiers-KNN and NB, International Journal of Science and Research, 4 (1), pp. 19041908.

[5] A. A. Shirazi, A. Dehghani, H. Farsi, and M. Yazdi, 2017. Persian logo recognition using local binary patterns, in: $3 r d$ International Conference on Pattern Analysis and Image Analysis, IPRIA 2017, IEEE.

[6] L. Breiman, 2001. Random forests, Machine Learning, 45 (1), pp. 5-32.

[7] S. Aygun and E. O. Gunes, 2017. A benchmarking: Feature extraction and classification of agricultural textures using LBP, GLCM, RBO, Neural Networks, k-NN, and random forest, in: 2017 6th International Conference on Agro-Geoinformatics, Agro-Geoinformatics 2017.

[8] F. Ahmad, K. Roy, B. O’Connor, J. Shelton, G. Dozier, and I. Dworkin, 2014. Fly Wing Biometrics Using Modified Local Binary Pattern, SVMs and Random Forest, International Journal of Machine Learning and Computing, 4 (3), pp. 279285.

[9] F. Tafazzoli, H. Frigui, and K. Nishiyama, 2017. A Large and Diverse Dataset for Improved Vehicle Make and Model Recognition, in: IEEE Computer Society Conference on Computer Vision and Pattern Recognition Workshops.

10] E. Prakasa, 2015. Texture Feature Extraction by Using Local Binary Pattern, Jurnal INKOM, 9 (2), pp. 45-48.

[11] T. Ojala, M. Pietikäinen, and T. Mäenpää, 2002. Multiresolution gray-scale and rotation invariant texture classification with local binary patterns, IEEE Transactions on Pattern Analysis and Machine Intelligence, 24 (7), pp. 971-987.

[12] I. Ali, Jehad; Khan, Rehanullah; Ahmad, Nasir; Maqsood, 2012. Random Forests and Decision Trees, International Journal of Computer Science Issues, 9 (5), pp. 272-278 